\title{
GIS IN LITHUANIAN FOREST INVENTORY - 20 YEARS' EXPERIENCE
}

\section{Ina Bikuviené ${ }^{1}$, Daiva Tiškutè-Memgaudiené}

\author{
${ }^{1}$ Kauno Kolegija - University of Applied \\ Sciences, \\ Pramonès pr. 20, Kaunas, Lithuania \\ ${ }^{2}$ Aleksandras Stulginskis University, \\ Kaunas dist., Lithuania
}

\begin{abstract}
:
It has been almost 20 years since the start of using GIS based stand-wise forest inventory and management in Lithuania. The first cycle of the stand-wise forest inventory by using GIS was finished in 2006. Lithuanian Institute for Forest Management Planning introduced the technologically new solution in 1999 in development of forest inventory by presenting the geographic information system (GIS). It started to work with PC/ArcInfo for data collection and storage as well as for cartographic works analysis. Later on, GIS system has evolved into a big and multifunctional digital information system, based on the ArcGIS, ArcSDE platforms and MS SQL Server. Technology was based on the integration of all cartographical material using GIS and on-screen vectorization of orthophoto maps. That has affected the foresters to change their approach to the benefits of using GIS technology in forest resources processing.
\end{abstract}

Key words:

forest management, Geographic Information System (GIS), geo-reference background.

\section{INTRODUCTION}

The planning and management of forest resources in Lihuania is known for a long time. The first references about forest conditions reach the 16th century. Regular forest inventories started in 1801-1820 and until 1914 all state's owned forests were inventoried at least once. (Mozgeris et al. 2008). During the period from 1922 to 1940, considerable attention was devoted to the forest measurement works and their accuracy. Forest plans were drawn by hand in scale 1:10000 or 1:5000. After 1950's for delineation of forest compartments started to use panchromatic ortophotomaps (Bikuviene, 2012). Usually, the forest inventory cycle in the state-owned forests in Lithuania is ten years. Forest management plans and cartographic material are prepared for the same period. Aerial photography is used for preparing cartographical material or orthophotomaps. Until 1990's, almost $85 \%$ of forests was covered with aerial phothography (Mozgeris et al. 2008).

In Lithuania, there are more than 2 millions ha of forests and every year about $10 \%$ of them (200-230 thousands of hectares) are inventoried. In 1984, digital data base for storing and processing of inventoried data was created. All data are analyzed, processed and then used for printing of reports. Data is updated according to the performed economic tools and the use of stand growth table. In a database more than 1,4 million 
records about forest compartments are stored, which are indicated with almost 100 parameters. This data base is used for statistic of ownerships, forest's cadastre, for forest planning and strategical development, for prediction of forest's condition, etc. (Mozgeris et al., 2008).

All forest inventory works are carried out by the Lithuanian Institute for Forest Management Planning by surveying and measuring every single individual stand. GIS database was developed for the first GIS-inventoried Biržai forest enterprise in the year 1995 by using manual digitizing from the paper topographic map with stand boundaries, transferred onto the maps from aerial photographs by using photo-mechanical projectors. Since 1996, orthophotographic maps have been used as a mapbase, while the manual digitizers were used to capture the geographic forest inventory data. Orthophotos based on special color infrared aerial photography have been used since 2002. These orthophotos are created specially for forest inventory and management planning purposes. Lithuanian Forest Inventory and Management Planning institute introduced technologically new solution in 1999 in development of forest inventory GIS databases. This technology is based on the integration of all cartographical material using GIS and on-screen vectorization of orthophoto maps. The main points of this technology are (Kuliešis et al.,2000; Kuliešis, 2002; Palicinas, 2007):

1. Collection of all available information to be used for possibly objective singling-out of the forest inventory units - forest stands (old forest maps, remote sensing data, general GIS databases and maps, measurements, etc.).

2. Automatization and integration of all collected information (scanning and geo-referencing of paper maps).

3. On-screen interpretation of new forest's compartment boundaries carried-out by forest's inventory's engineers. The same person will implement the field work and finalization of the compartment level GIS database later.

4. Development of initial version of forest compartment GIS database and printing-out of sketch maps for field surveys.

5. Conventional field survey.

6. Finalization of forest compartment GIS database, development of cartographic elements, calculation of some specific attributes (area), mapping, etc. using conventional techniques.

The first cycle of the stand-wise forest inventory using GIS was finished in 2006 in Lithuania. The technologies used for forest inventories were redesigned essentially during the first decade. The last of them was on-screen vectorization of colour infrared orthophotos, assisted with numerous auxiliary information, including maps from previous forests' inventories and georeference GIS databases.

\section{THE INFLUENCE OF DIFFERENT INVENTORY TECHNIQUES ON THE GEOMETRICAL ACCURACY OF FOREST GEOGRAPHIC DATA}

It was expected that innovation was enabled to obtain more accurate data than using manual digitizing. However, this has been tested only few times. Moreover, there is practically no information on the geometrical accuracy of geographic data, collected during standwise forest inventories. Some publications are about the quality of orthophotos used for inventory (Mozgeris and Dumbrauskas, 2006), but only theoretic accuracy assumptions are done in the technological descriptions of works. The instruction of forest inventory and management planning activities provides just the requirements for GIS data basis accuracy that is expected. According to the instructions, the geographic accuracy by clearly identifying objects in the area and in the GIS database or cartographic plans (such as section line, hydrographic network elements and others crossings, road junctions, etc.) positional accuracy root mean square error (RMSE) cannot by greater than $5 \mathrm{~m}$ (http://www3.lrs.lt/...).

The positional accuracy of forest GIS base was tested by comparing different technological solutions. Identical object on two GIS databases - forest compartment GIS database at a scale of 1:10000, was developed within the frames of stand-wise forest inventories and Lithuanian georeference background data base GDB10LT. Approximately, 2500 of control points were located on both databases (Figure 1). Clearly identifiable objects on both databases, such as road, dike intersections, sharp corners of forest tracts, etc., have been digitized (Figure 2).

Euclidean distances between points were calculated, as well as the distances at $\mathrm{X}$ and $\mathrm{Y}$ directions. GDB10LT was considered as the standard. Conventional accuracy estimates, such as bias, location root mean square error, including the ones in $\mathrm{X}$ and $\mathrm{Y}$ directions, standard deviations were calculated. Standard ArcGIS software was used for capturing the control points and calculating the accuracy estimates.

The results have shown, that the biggest and not acceptable errors at a scale of 1:10000 were achieved in the 


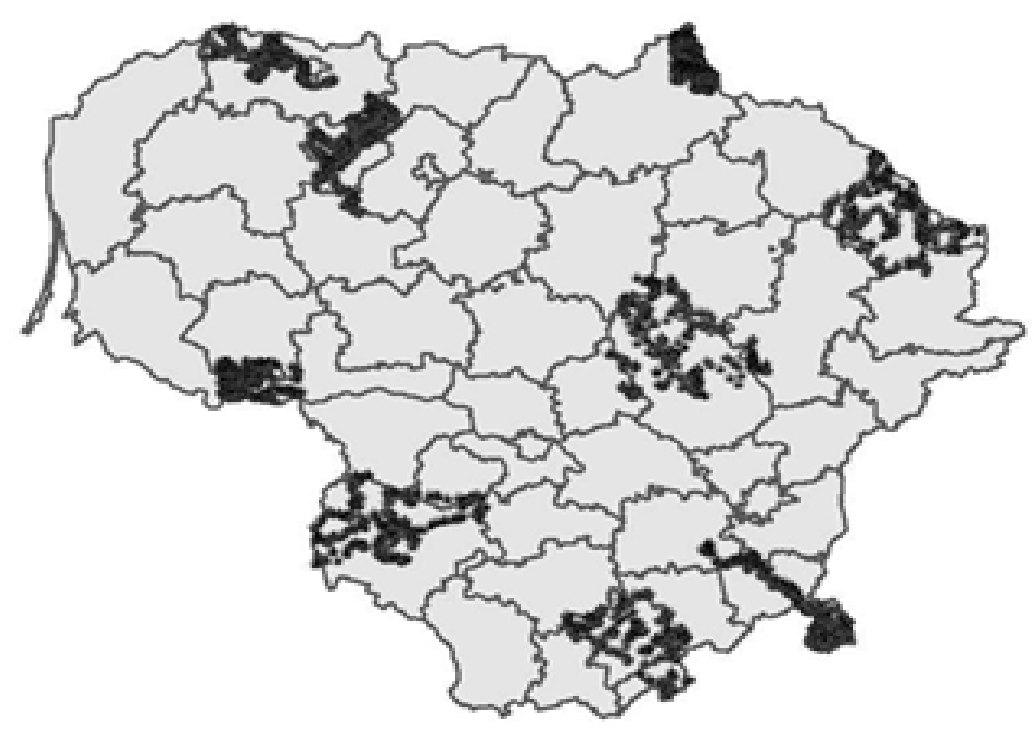

Figure 1. Locations of control points on the Lithuanian forest directorate

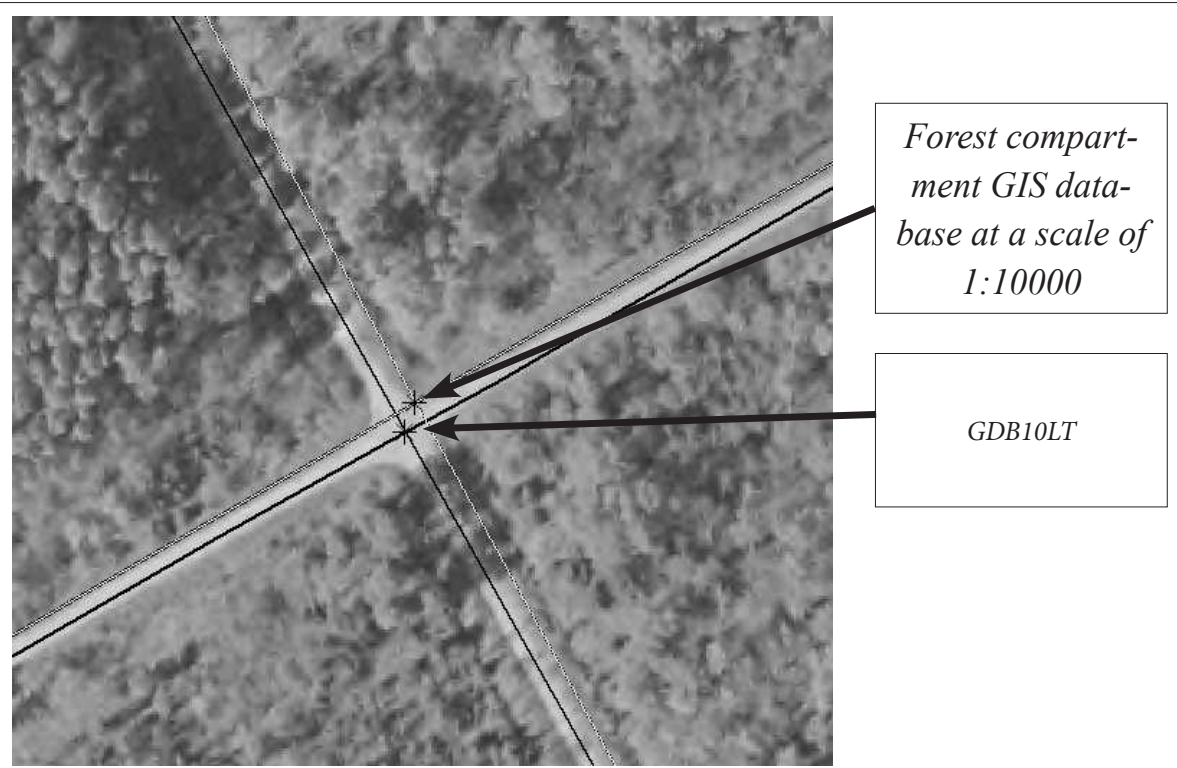

Figure 2. Locations of control points on the Lithuanian forest directorate

first steps of using GIS. The largest root meaning square errors (12.37 $\mathrm{m}$ and $10.87 \mathrm{~m}$, for $\mathrm{X}$ and $\mathrm{Y}$ coordinates respectively) was found on a version of forest compartment GIS database, which was developed by using manual digitizing of topographic maps. The overall root meaning square error here was 16.47 and the bias $-13.2 \mathrm{~m}$. The geometric accuracy of forest compartment GIS database seems to improve steadily with the introduction of more advance techniques. Introduction of coloured infrared orthophotos instead of panchromatic ones has resulted in slightly decreased geometrical accuracy of clearly identifiable forest objects. It should be noted that coloured infrared orthophotos are focused on improving forest's stand delineation but not for detecting of topographic objects, such as rods and dikes. The geometrical accuracy of forest inventory oriented colour infrared orthophotos is somewhat less than the one of panchromatic orthophotos (Mozgeris and Dumbrauskas, 2003).

The results achieved lead to the conclusion that forest compartments GIS databases, created two decade ago, failed to meet the requirements of mapping at a scale 1:10000. Nevertheless, all technological innovations in development of forest inventory GIS databases have had positive influence on the geometrical accuracy of well-defined geographic objects. The best results were achieved with an introduction of on-screen vectorization techniques. Errors have reduced below the level required for mapping at a scale of 1:10000 (Bikuvienè, 2008). 


\section{INTEGRATION OF GIS IN ALL FOREST INVENTORY, MANAGEMENT AND CONTROL STAGES}

All of these innovations have been used for creation of GIS based system for forest cadastre and management. Lithuanian Institute for Forest Management Planning established department for GIS and cartography. GIS evaluation has taken all the stages from a simple system, based on ArcView, then to ArcGIS ArcInfo, and finally to ArcSDE platforms and MS SQL Server's. For the purpose of improving the quality of forest inventory and management data, GIS is used in almost all stages of works. Inside the company, all departments can use the GIS database as clients of centralized server with different levels of management. Outside users can connect to the centralized server for a browsing for different types of forest information. GIS system is created like an integrated and flexible system and can work with different types of data, not only collected with devices, using an ArcGIS platform.

Lithuanian State Forest Service has created an MGIS system based on ArcGIS Viewer for Flex, which provides information about forests managements plans in private and state forests, forest's conditions after natural events (windstorms, fires), land utilities, forests compartments, etc. (http://www.amvmt.lt:81/mgis/). Every single user can browse this information for free (Figure 3).

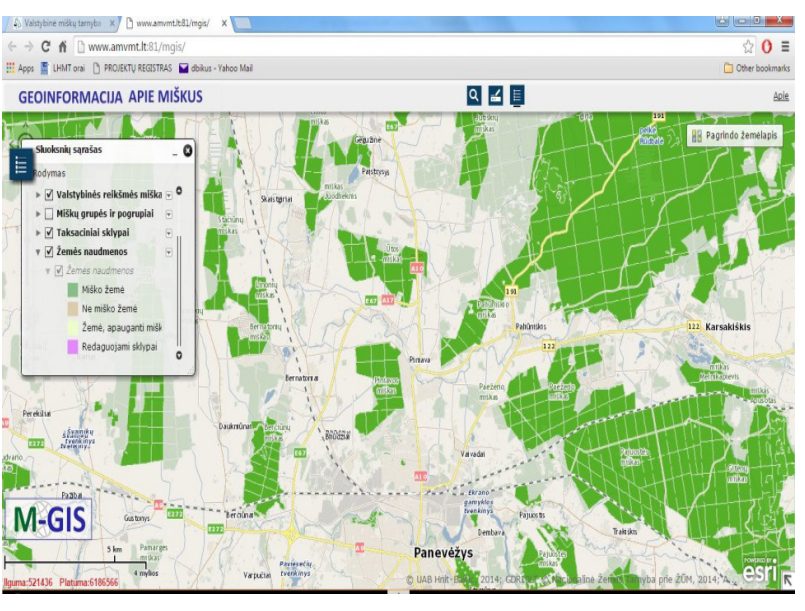

Figure 3. Example of MGIS

One more GIS database was created for employees working in the territorial divisions, with the possibility of editing data from their workplaces all around the Lithuania (http://www.amvmt.lt:81/vmtgis). Authorised users can edit, browse, print and analyse data. For both databases mentioned above, Lithuanian georeference background database GDB10LT and orthophotomaps of different years, are used as background.

The introduction of more accurate positional devices, such as GPS receivers (Trimble Juno series) or field computers, improved the accuracy of collected data. After the field surveying, it is possible to move collected data directly to the database. For field works all devices are prepared with digital forests compartment maps. There are a lot of different layers, with important data for forests inventory purposes: forests classes, ownerships of forests, cadastral parcels borders, protected areas, etc. The field surveyors can create a preliminary version of GIS and transfer it later directly to the database. For field works papermaps are prepared, on which old borders are given of forest's compartments and forest's borders itself, protected areas, cadastral information, etc. All corrections are performed on them, and later vectorized on a screen by GIS specialist (Figure 4).

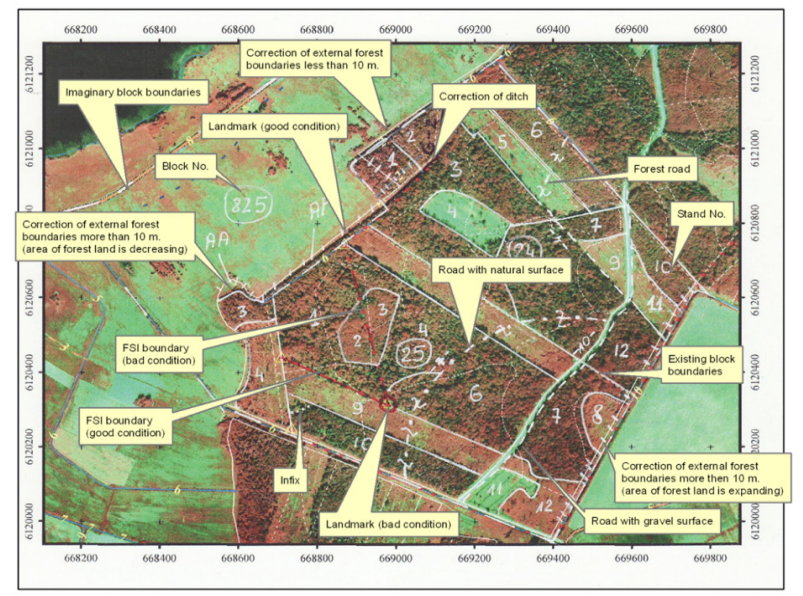

Figure 4. Example of a papermap, used by field surveyors

In a GIS database, created after field works, are stored not only the vector data, but the descriptive information too. After field works, a preliminary version of GIS databases are updated and supplemented with exhaustive descriptive data (Mozgeris et al., 2008). Different kinds of thematics maps for forest inventory are created in a digital form, which can later be printed or submitted to the recipients in digital form.

\section{GIS SIGNIFICANCE FOR THE LITHUANIAN FOREST SYSTEM}

After the first decade of using GIS in forest inventory works, the users - forest enterprises or private foresters were asked about their opinion or expierence with GIS. 
An interview was made with more than 100 foresters (Mozgeris et al., 2008). None of them was a GIS specialist. The use of GIS in the forestry was rated on the scale from 4 to 10 (10- excellent, 4 - unsatisfactory) and the results was 5,5. The question, „What is your opinion about the benefits of innovation by using GIS, digital maps, orthomaps for forest inventory?", was answered not only by the users of end production- different kind of maps, plans, etc. - but the field surveyors too. None of them have answered like „““. This gave a hope, that innovation will be used and integrated to all works in the forest.

This interview was repeated this year by asking the state forest enterprises to determine the situation related to the current use of GIS. Of 42 forests' enterprises, the answers were obtained from 25 . In 2004, only three enterprises were using GIS software, 14 were planning to buy it. Today, 20 forest enterprises are using GIS software, while 2 are planning to buy it. The number of people with experience in working with GIS has reached almost 200. Number of GIS personal desktops is around 130. All of respondents have answered that they use GIS in fieldworks. This leads to the conclusion that GIS has become more important for the foresters and in the future all works will be performed by using GIS software.

\section{CONCLUSIONS}

Technological innovations in development of forest inventory GIS databases have had positive influence on the geometrical accuracy of well-defined geographic objects.

GIS has evolved to an integrated and flexible system, used in all stages of forest inventory, management and control.

More than a half of forest enterprises are using GIS software or will use it in the nearest future.

GIS has become very important for foresters and in the future, all works will be performed by using GIS software.

\section{REFERENCES}

Bikuvienè, I. (2008). The influence of different inventory techniques on the geometrical accuracy of forest geographic data. Research for Rural development 2008, Annual 14'th international Scientific conference, 21-23 May 2008 (pp. 117-122). Jelgava, Latvia: Latvia University of Agriculture.

Bikuvienė, I. (2012). Theoretical and practical improvement of forest inventory by using laser scanning. Phd thesis, p. 99.

Kuliešis, A.A., Mozgeris, G. (2000). Using digital orthophotomaps and other maps in forest stand delineation. III international symphosium „Aplication of remote sensing in forestry", 12-14 September 2000 (pp. 259-260). Zvolen, Slovakia.

Kuliešis, A.A. (2002). Valstybinis miškotvarkos institutas nepriklausomoje Lietuvoje: kartografinès medžiagos parengimo grupé. Lietuvos miškotvarka ir jos raida. Kaunas, pp. 102-104 (in Lithuanian).

Mozgeris, G., Dumbrauskas, A. (2003), Ortofotografiniu transformuotų aerovaizdų, sudaromų miškų inventorizacijos tikslams, geometrinio tikslumo tyrimai (Investigation of geometrical accuracy of ortho photos, produced for forest inventory aims). Geografijos metraštis, 36(1), pp. 237-249 (in Lithuanian).

Mozgeris, G., Galaunè, A., Palicinas, M., (2008). Systemy informacji geograficznej w urząndzaniu lasu na Litwie - dekada praktycznego stosowania. Sylvan, 1, pp. 58-63.

Palicinas, M. (2007). GIS panaudojimas Valstybiniame miškotvarkos institute (Use of GIS in Lithuanian Institute for Forest Management Planning)

Valstybinè miškų tarnyba (2010). Isakymas dèl miškotvarkos darbu vykdymo instrukcijos patvirtinimo from http://www3.lrs.lt/pls/inter3/dokpaieska. showdoc_l?p_id $=370142 \&$ p_query $=\& p \_t r 2=$

http://www.amvmt.lt:81/vmtgis

http://www.amvmt.lt:81/mgis 